Zeszyty Naukowe Szkoły Głównej Gospodarstwa Wiejskiego

Ekonomika i Organizacja Gospodarki Żywnościowej nr 121 (2018), 105-114

DOI 10.22630/EIOGZ.2018.121.8

\author{
Julita Szlachciuk \\ Wydział Nauk o Żywieniu Człowieka i Konsumpcji \\ Szkoła Główna Gospodarstwa Wiejskiego w Warszawie
}

\title{
Znajomość praw przysługujących konsumentom dokonującym zakupu żywności przez Internet
}

\begin{abstract}
Abstrakt: Celem artykułu jest ocena znajomości praw przysługujących konsumentom dokonującym zakupów żywności przez Internet. Badanie zrealizowano wśród 600 respondentów będących w wieku 25-44 lat, dokonujących zakupu żywności przez Internet. Uzyskane wyniki potwierdzają, że rodzaj informacji udostępnianych przez przedsiębiorców, sposób ich podawania (które są konsekwencją obowiązujących regulacji prawnych) mogą przyczyniać się do postrzegania zakupów w sieci jako dobrej alternatywy tradycyjnych form sprzedaży żywności (sklepy stacjonarne). Jednocześnie warto zwrócić uwagę, że część ankietowanych nie potrafiła jednoznacznie ustosunkować się do praw przysługujących konsumentom podczas zakupu żywności przez Internet, nie zawsze też jest świadoma zasad składania reklamacji, co wskazuje na konieczność dalszego prowadzenia działań edukacyjnych skierowanych do konsumentów w tym zakresie.
\end{abstract}

Słowa kluczowe: Internet, zakup żywności, ochrona konsumentów, znajomość praw Kody JEL: D18, K15

\section{Wstęp}

W Europie szybko wzrasta zainteresowanie zakupami w sklepach internetowych, także tych związanych z zakupami żywności. W Polsce z usług sklepów internetowych również korzysta coraz więcej osób. Według wskaźnika DESI (ang. Digital Economy and Society Index) ${ }^{1}$ w 2017 roku w Polsce wskaźnik ten wynosił

\footnotetext{
julita_szlachciuk@sggw.pl, SGGW, WNoŻCziK, ul. Nowoursynowska 159c, 02-776 Warszawa

${ }^{1}$ Wskaźnik opracowany przez Komisję Europejską. Służy ocenie rozwoju krajów UE w zakresie gospodarki cyfrowej i społeczeństwa cyfrowego. Obejmuje zestaw pięciu współczynników dotyczących: łączności, kapitału ludzkiego, korzystania z Internetu, integracji technologii cyfrowych oraz cyfrowych usług publicznych. Wskaźnik przyjmuje wartości od 0 do 1.
} 
0,43 (Unia Europejska - 0,52). Polska uplasowała się na 23. miejscu na liście państw Unii Europejskiej [EC 2017b]. Z jednej strony handel elektroniczny kreuje nowe trendy rynkowe, z drugiej zaś musi sprostać rosnącym wymaganiom konsumentów [Majchrzak-Lepczyk 2015].

Z roku na rok rośnie znaczenie sprzedaży internetowej artykułów spożywczych i staje się ona coraz ważniejszym źródłem przychodów w międzynarodowych sieciach sprzedażowych. Niekwestionowaną przewaga Internetu jest personalizacja zgodna z preferencjami konsumenta, bowiem tak indywidualnego podejścia nie zapewnia dziś żaden supermarket [Portalspożywczy.pl 2017].

Według danych z raportu „E-Commerce w Polsce 2016. Gemius dla e-Commerce Polska", który powstał na podstawie badania zrealizowanego w maju 2016 roku na grupie 1500 internautów w wieku 15 i więcej lat, forma zakupów przez Internet jest tańsza, wygodniejsza i umożliwia większy wybór w porównaniu z tradycyjnymi kanałami handlu. W odniesieniu do żywności prawie co czwarty ankietowany deklarował, że kupił żywność (23\%) lub zamierza kupować w przyszłości (27\%), nieco częściej tę chęć zakupu w przyszłości deklarowały kobiety niż mężczyźni (odpowiednio: 30 i 24\%) [Gemius 2016]. Coraz częściej Internet jest także pierwszym źródłem informacji o produktach żywnościowych, szczególne dla młodych konsumentów [Gębski i in. 2017].

W odniesieniu do artykułów żywnościowych należy jednak zwrócić uwagę na to, że ich sprzedaż przez Internet jest trudna do realizacji z powodu fizycznych cech produktu łatwo się psującego. Wymaga to bardzo sprawnego pośrednictwa w fizycznej dostawie [Cyrek 2013]. Obawy osób niekupujących w sieci wiążą się głównie z potencjalnym szeroko rozumianym ryzykiem korzystania z zakupów w sieci oraz ich zdaniem mniejszą możliwością wyboru produktów niż w tradycyjnych sklepach [Gemius 2016]. Inne przeszkody to m.in. brak możliwości przyjrzenia się produktom i brak gwarancji ich jakości. Dodatkowym utrudnieniem dla sprzedawców bywają też skomplikowane regulacje prawne dotyczące sprzedaży żywności i sprzedaży internetowej [Portalspożywczy.pl 2017].

Według ustawy z 2014 roku o prawach konsumenta umowa zawarta na odległość to taka, którą zawarto $\mathrm{z}$ konsumentem w ramach zorganizowanego systemu zawierania umów na odległość, bez jednoczesnej fizycznej obecności stron, z wyłącznym wykorzystaniem jednego lub większej liczby środków porozumiewania się na odległość do chwili zawarcia umowy włącznie. Ten akt prawny nakłada na przedsiębiorcę bardzo obszerny obowiązek informacyjny dotyczący ogólnych zasad prowadzenia sprzedaży dzięki środkom porozumiewania się na odległość.

Według danych z raportu „E-Commerce w Polsce 2016. Gemius dla e-Commerce Polska" respondenci deklarowali, że szukają w serwisach internetowych dokładnych informacji o produktach żywnościowych (zagregowane odsetki odpowiedzi ,zawsze i często" stanowiły 36\%), a tylko 15\% ankietowanych zadeklarowało sytuację odwrotną, że szukali dokładnych informacji o produktach żywnościowych 
w tradycyjnych sklepach, ale kupują w serwisach internetowych. Warto więc podkreślić, że rozporządzenie Parlamentu Europejskiego i Rady (UE) 1169/2011 nakłada z jednym wyjątkiem taki sam obowiązek informowania konsumenta o żywności podczas jej zakupu w sposób tradycyjny i przez Internet. W rozporządzeniu tym podkreślono, że w przypadku żywności opakowanej oferowanej do sprzedaży za pośrednictwem środków porozumiewania się na odległość: obowiązkowe są informacje na temat żywności zawarte w art. 9, z wyjątkiem danych szczegółowych określonych w art. 9 ust. 1 lit. f, tj. data minimalnej trwałości lub termin przydatności do spożycia, muszą być dostępne przed ostatecznym dokonaniem zakupu i muszą znajdować się w materiałach towarzyszących sprzedaży na odległość lub być dostarczane z użyciem innych właściwych środków wyraźnie określonych przez dany podmiot działający na rynku żywności. Obowiązkowe informacje na temat żywności dostarcza się bez obciążania konsumentów dodatkowymi kosztami przez podmiot działający na rynku żywności. Wszystkie obowiązkowe dane szczegółowe muszą być dostępne w momencie dostawy. Ponadto warto podkreślić, że w cytowanym rozporządzeniu zdefiniowano pojęcie środków porozumiewania się na odległość jako wszelkie środki, które bez jednoczesnej fizycznej obecności dostawcy i konsumenta mogą być wykorzystane do zawarcia umowy między tymi stronami.

Celem artykułu jest określenie poziomu wiedzy konsumentów dotyczącej przysługujących im praw i istniejących obowiązków przy zawieraniu umów zakupu żywności za pomocą środków porozumiewania się na odległość.

\section{Materiał i metodyka}

Badanie zostało zrealizowane w grudniu 2015 roku. W pierwszym etapie w doborze próby badawczej został zastosowany dobór jednostek typowych, który polegał na wyborze grupy badanych dokonujących zakupów żywności w Internecie. Następnie przeprowadzono badanie z wykorzystaniem metody CATI (telefoniczne wywiady wspomagane komputerowo) na losowo wybranej próbie dorosłych mieszkańców Polski. Na potrzeby niniejszego artykułu analizie poddano wyniki pochodzące od 600 respondentów w wieku od 25 do 44 lat. Badanie zostało zrealizowane z wykorzystaniem zaprojektowanego w tym celu autorskiego kwestionariusza ankiety. W kwestionariuszu umieszczono 16 pytań, w tym sześć dotyczyło cech socjodemograficznych ankietowanych (tab. 1). Badanie przeprowadzono przez wyłonioną w postępowaniu ofertowym agencję badawczą stosującą standardy ESOMAR.

Uzyskane wyniki poddano analizie statystycznej. Przyjęto poziom istotności statystycznej $\alpha=0,05$. Do zbadania istotności statystycznej różnic między cechami socjodemograficznymi użyto testu $\chi^{2}$. Analizę danych przeprowadzono z użyciem programu statystycznego IBM SPSS Statistics. Badana próba liczyła: 147 osób w wieku 25-29 lat (24,5\%), 149 osób w wieku 30-34 lata (24,8\%), 152 osoby w wie- 


\section{Tabela 1}

Charakterystyka badanej próby

\begin{tabular}{|c|c|c|}
\hline \multicolumn{2}{|l|}{ Wyszczególnienie } & $\%$ odpowiedzi \\
\hline \multirow{2}{*}{ Płeć } & kobiety & 55,0 \\
\hline & mężczyźni & 45,0 \\
\hline \multirow{4}{*}{ Wiek } & 25-29 lat & 24,5 \\
\hline & 30-34 lata & 24,8 \\
\hline & 35-39 lat & 25,3 \\
\hline & 40-44 lata & 25,3 \\
\hline \multirow{3}{*}{ Poziom wykształcenia } & podstawowe i zawodowe & 10,7 \\
\hline & średnie & 50,3 \\
\hline & wyższe & 39,0 \\
\hline \multirow{3}{*}{ Sytuacja materialna } & bardzo zła/zła & 1,0 \\
\hline & ani dobra, ani zła & 30,0 \\
\hline & dobra/bardzo dobra & 69,0 \\
\hline \multirow{4}{*}{ Miejsce zamieszkania } & wieś & 12,8 \\
\hline & miasto o zaludnieniu do 50 tys. mieszkańców & 29,8 \\
\hline & $\begin{array}{l}\text { miasto o zaludnieniu od } 50 \text { do } 100 \text { tys. } \\
\text { mieszkańców }\end{array}$ & 36,2 \\
\hline & miasto o zaludnieniu > 100 tys. mieszkańców & 21,2 \\
\hline
\end{tabular}

Źródło: Badanie własne.

ku 35-39 lat (25,3\%) oraz 152 osoby w wieku 40-44 lata $(25,3 \%)$. W badanej grupie przeważały kobiety (55,0\%). Mieszkańcy miast o zaludnieniu więcej niż 100 tys. mieszkańców stanowili 21,2\% badanej populacji. Mieszkańcy wsi stanowili 12,8\%. Wyższy poziom wykształcenia deklarowało 39,0\% ankietowanych (tab. 1).

\section{Wyniki badań własnych i ich dyskusja}

Większość ankietowanych stwierdziła, że ich poziom znajomości praw przysługujących konsumentom dokonującym zakupów żywności przez Internet jest dobry lub bardzo dobry (57,5\%). Najczęściej takiej odpowiedzi udzielali respondenci deklarujący wyższe wykształcenie $(66,7 \%)$ oraz osoby mieszkające w miastach o zaludnieniu powyżej 100 tys. mieszkańców (66,1\%). Zarówno poziom wykształcenia respondentów, jak i miejsce ich zamieszkania różnicowały w sposób istotny statystycznie odpowiedzi respondentów w tym zakresie $(\mathrm{p} \leq 0,05)$.

Analizując odpowiedzi ankietowanych na poszczególne stwierdzenia dotyczące znajomości praw przysługujących konsumentom dokonującym zakupów żywności przez Internet, odnotowano, że najwięcej ankietowanych prawidłowo zgadzało 
się ze stwierdzeniem, że „każdy sklep internetowy powinien mieć regulamin zamieszczony na swojej stronie" (67,7\%). Tylko 5,7\% badanych udzieliło poprawnej odpowiedzi na stwierdzenie „kupując żywność przez Internet, mam więcej czasu na reklamację produktu, niż kupując ją w tradycyjnym sklepie”. Zgodnie bowiem z zapisem w kodeksie cywilnym dotyczącym uprawnień wynikających z tytułu rękojmi nie ma żadnego różnicowania w terminie składania reklamacji w zależności od formy sprzedaży (tradycyjna czy przez Internet). Biorąc pod uwagę wszystkie odpowiedzi respondentów, odnotowano, że w przypadku wszystkich stwierdzeń około 1/3 ankietowanych nie potrafiła jednoznacznie ustosunkować się do zaprezentowanych stwierdzeń (tab. 2).

\section{Tabela 2}

Znajomość poszczególnych praw przysługujących konsumentom dokonującym zakupów żywności przez Internet [\%]

\begin{tabular}{|l|c|c|c|}
\hline Wyszczególnienie & $\begin{array}{c}\text { Zdecydowanie się } \\
\text { nie zgadzam/nie } \\
\text { zgadzam się }\end{array}$ & $\begin{array}{c}\text { Ani się } \\
\text { zgadzam, } \\
\text { ani się nie } \\
\text { zgadzam }\end{array}$ & $\begin{array}{c}\text { Zgadzam się/ } \\
\text { /zdecydowanie się } \\
\text { zgadzam }\end{array}$ \\
\hline $\begin{array}{l}\text { Każdy sklep internetowy powinien mieć } \\
\text { regulamin zamieszczony na swojej stronie }\end{array}$ & 3,8 & 28,5 & 67,7 \\
\hline $\begin{array}{l}\text { Można w ciagu 14 dni odstapić od umowy } \\
\text { zawartej na odległość bez podawania } \\
\text { przyczyny }\end{array}$ & 3,3 & 36,0 & 60,7 \\
\hline $\begin{array}{l}\text { Jeżeli konsument odstępuje od umowy } \\
\text { zawartej na odległość, ponosi również koszty } \\
\text { odesłania towaru do przedsiębiorcy }\end{array}$ & 5,2 & 36,8 & 58,0 \\
\hline $\begin{array}{l}\text { Kupując żywność przez Internet, mam więcej } \\
\text { czasu na reklamację produktu, niż kupując ją } \\
\text { w tradycyjnym sklepie }\end{array}$ & 5,7 & 40,4 & 53,9 \\
\hline
\end{tabular}

Źródło: Badanie własne.

Z opublikowanych przez Komisję Europejską danych za 2017 rok dotyczących sytuacji konsumentów w Unii Europejskiej wynika, że w porównaniu z deklaracjami z 2015 roku konsumenci są bardziej świadomi swoich praw. Średnio 13\% konsumentów zna podstawowe prawa przysługujące podczas dokonywania zakupów w Internecie. Nie poprawiła się jednak znajomość praw konsumentów wśród sprzedawców. Odnotowano, że poziom wiedzy sprzedawców różni się także w zależności od kraju: prawa konsumentów zna 36,2\% sprzedawców detalicznych w Chorwacji, taką wiedzą może wykazać się 62,3\% niemieckich sprzedawców [EC 2017a].

Uwzględniając poziom wykształcenia respondentów, odnotowano, że w przypadku trzech pierwszych stwierdzeń osoby z wyższym wykształceniem udzielały najczęściej poprawnych odpowiedzi. Nie odnotowano w tym przypadku zależności 
istotnych statystycznie. Prawidłowej odpowiedzi na stwierdzenie „kupując żywność przez Internet, mam więcej czasu na reklamację produktu, niż kupując ją w tradycyjnym sklepie" udzielali najczęściej ankietowani w wieku 30-34 lata (9,4\%) oraz mieszkańcy miast o zaludnieniu powyżej 100 tys. mieszkańców (7,9\%). Wiek różnicował istotnie statystycznie opinie ankietowanych w tym zakresie $(\mathrm{p} \leq 0,05)$.

Ankietowani zostali poproszeni również o ocenę spełnienia obowiązków informacyjnych przez sprzedawców internetowych. Respondenci najczęściej przyznawali, że na stronie sklepów internetowych, w których kupują żywność, były zamieszczone informacje dotyczące: nazwy i danych adresowych przedsiębiorstwa $(90,0 \%)$, istotnych właściwości świadczenia i jego przedmiotu $(86,8 \%)$ oraz ceny obejmującej wszystkie jej składniki (77,8\%). Ankietowani przyznawali, że najrzadziej spotkali się z informacją dotyczącą możliwości skorzystania z pozasądowych sposobów rozpatrywania reklamacji i dochodzenia roszczeń oraz zasadach dostępu do tych procedur $(66,3 \%)$ - tabela 3 .

\section{Tabela 3}

Spełnienie obowiązków informacyjnych przez sprzedawców internetowych w opinii respondentów

\begin{tabular}{|l|c|}
\hline Informacje udostępniane na stronie internetowej sprzedawców & $\%$ wskazań \\
\hline Nazwa i dane adresowe przedsiębiorstwa & 90,0 \\
\hline $\begin{array}{l}\text { Istotne właściwości świadczenia i jego przedmiotu (opis towaru lub usługi, jego istotnych } \\
\text { cech, parametrów, zastosowań itd.) }\end{array}$ & 86,8 \\
\hline Cena obejmująca wszystkie jej składniki & 77,8 \\
\hline Koszty oraz termin i sposób dostawy & 75,0 \\
\hline Miejsce i sposób składania reklamacji & 71,8 \\
\hline Prawo do odstapienia od umowy ze wskazaniem wyjątków & 70,0 \\
\hline $\begin{array}{l}\text { Możliwość skorzystania z pozasądowych sposobów rozpatrywania reklamacji i dochodzenia } \\
\text { roszczeń oraz zasad dostępu do tych procedur }\end{array}$ & 66,3 \\
\hline
\end{tabular}

Źródło: Badanie własne.

Z badania przeprowadzonego przez Gemius w 2017 roku wśród 1500 internautów wynika, że zakupy w Internecie mają pozytywny wizerunek. Respondenci, którzy dokonali w przeszłości takich zakupów, postrzegają je przede wszystkim jako łatwe i wygodne. Obawy osób deklarujących niekupowanie w sieci związane są przede wszystkim z bezpieczeństwem e-zakupów [Gemius 2017]. Niespełnienie bądź nienależyte wypełnienie obowiązków informacyjnych przez przedsiębiorcę w istotny sposób modyfikuje uprawnienia stron poprzez rozszerzenie znacznie praw konsumenta i zawężenie uprawnień przedsiębiorcy. Warto także w tym miejscu podkreślić, że ustawa o prawach konsumenta wprowadziła do kodeksu wykroczeń nowy art. (139 b), który za niedopełnienie obowiązków informacyjnych zawartych w ustawie o prawach konsumenta przewiduje karę grzywny: „Kto w zakresie działalności swojego przedsiębiorstwa zawierając umowę z konsumentem nie spełnia wymagań 
dotyczących udzielenia informacji lub wydania dokumentu, przewidzianych w przepisach ustawy z dnia 30 maja 2014 r. o prawach konsumenta (Dz.U. poz. 827), podlega karze grzywny".

Prawie $70 \%$ ankietowanych przyznało, że cena na stronach sklepów internetowych, w których kupowali żywność, była zawsze jasno sformułowana. Z uwagi na to, że cena jest jednym z najważniejszych czynników skłaniających konsumentów do zakupu żywności przez Internet [Chu i in. 2008, Maciaszczyk 2014, Komor i in. 2015, Grzywińska-Rapca i Grzybowska-Brzezińska 2016] zasadne jest to, aby sprzedawcy dołożyli wszelkiej staranności w celu poprawnego jej uwidocznienia.

Połowa respondentów zgadzała się ze stwierdzeniem, że dostęp do informacji na temat zasad reklamacji jest łatwiejszy w przypadku zakupu żywności przez Internet. Tylko 3,5\% badanych nie zgodziło się ze stwierdzeniem, że regulaminy czy ogólne warunki umów stosowane przez sprzedawców oferujących żywność w Internecie są sformułowane w sposób jasny i zrozumiały dla przeciętnego konsumenta (tab. 4).

\section{Tabela 4}

Opinie respondentów na temat formułowania wybranych informacji przekazywanych konsumentom przez sprzedawców [\%]

\begin{tabular}{|l|c|c|c|}
\hline Wyszczególnienie & $\begin{array}{c}\text { Zdecydowanie się } \\
\text { nie zgadzam/nie } \\
\text { zgadzam się }\end{array}$ & $\begin{array}{c}\text { Ani się } \\
\text { zgadzam, } \\
\text { ani się nie } \\
\text { zgadzam }\end{array}$ & $\begin{array}{c}\text { Zgadzam się/ } \\
\text { Izdecydowanie się } \\
\text { zgadzam }\end{array}$ \\
\hline $\begin{array}{l}\text { Cena, którą muszę zapłacić za zakupy przez } \\
\text { Internet jest zawsze jasno sformułowana }\end{array}$ & 4,7 & 35,2 & 69,0 \\
\hline $\begin{array}{l}\text { Sprzedawcy oferujący towary lub usługi } \\
\text { w Internecie udostępniaja wszystkie istotne } \\
\text { informacje dotyczące warunków umowy }\end{array}$ & 3,8 & 34,0 & 62,2 \\
\hline $\begin{array}{l}\text { Regulaminy czy ogólne warunki umów } \\
\text { stosowane przez sprzedawców oferujących } \\
\text { żywność w Internecie są sformułowane } \\
\text { w sposób jasny i zrozumiały dla przeciętnego } \\
\text { konsumenta }\end{array}$ & 3,5 & 36,0 & 60,5 \\
\hline $\begin{array}{l}\text { Dostęp do informacji na temat zasad reklamacji } \\
\text { jest łatwiejszy w przypadku zakupu żywności } \\
\text { zakupionej przez Internet }\end{array}$ & 5,3 & 42,3 & 52,4 \\
\hline
\end{tabular}

Źródło: Badanie własne.

Ze stwierdzeniem dotyczącym sposobu sformułowania ceny $(65,4 \%)$ oraz stwierdzeniem mówiącym o spełnieniu obowiązku informacyjnego przez sprzedawców internetowych $(68,5 \%)$ najczęściej zgadzali się mieszkańcy dużych miast. Z kolei dla większości ankietowanych kobiet regulaminy czy ogólne warunki umów stosowane przez sprzedawców oferujących żywność w Internecie były sformułowa- 
ne w sposób jasny i zrozumiały dla przeciętnego konsumenta $(64,5 \%)$. We wszystkich przypadkach nie odnotowano zależności istotnych statystycznie.

Z badań przeprowadzonych przez Katedrę Rynku i Konsumpcji Uniwersytetu Ekonomicznego w Katowicach na próbie 1100 osób wynika, że osoby dokonujące zakupów w Internecie (w tym zakupów żywności) uważają, że taka forma zakupów ułatwia dostęp do wielu produktów i usług oraz pozwala zaoszczędzić czas. W większości badani stwierdzili, że ten sposób dokonywania zakupów nie jest zbyt skomplikowany i prognozują, że konsumenci będą coraz chętniej kupować usługi w Internecie niż tradycyjnie w placówkach usługowych [Wolny 2016]. W badaniu przeprowadzonym wśród studentów Politechniki Koszalińskiej w wieku 20-23 lata, którzy w większości dokonywali zakupów w Internecie na platformie Allegro, odnotowano, że $1 / 4$ ankietowanych otrzymała towar niezgodny z opisem, ale ponad $60 \%$ badanych nigdy nie reklamowało zakupionego produktu. Ponad $1 / 3$ badanych przyznała, że tylko raz reklamowała towar zakupiony przez Internet [Deluga i Dyczkowska 2011]. W przypadku zakupu żywności na mały odsetek osób decydujących się na złożenie reklamacji może mieć wpływ niska (z reguły) cena produktów żywnościowych. Badanie Balon [2015] pokazuje jednak, że niektórzy konsumenci reklamują wszystkie wadliwe produkty, nawet te najtańsze. Inni reklamują tylko te produkty, które są droższe.

\section{Podsumowanie}

Wyniki badań potwierdzają, że stosunkowo wysoko oceniany jest przez respondentów poziom ochrony konsumentów dokonujących zakupu żywności przez Internet. Dotyczy to zarówno rodzaju informacji udostępnianych przez przedsiębiorców, jak i sposobu ich podawania, co jest konsekwencją obowiązujących regulacji prawnych. Może się to przyczyniać do postrzegania zakupów w sieci jako dobrej alternatywy tradycyjnych form sprzedaży żywności (sklepy stacjonarne). Potwierdzeniem tego są dane Eurostatu za 2015 roku, z których wynika, że 82\% polskich konsumentów w ciagu ostatnich 12 miesięcy nie miało żadnych problemów w czasie zakupów przez Internet. W przypadku Unii Europejskiej odsetek ten wyniósł $70 \%$. Polscy konsumenci także mniej obawiają się o bezpieczeństwo płatności ( $6 \%$; UE-28 - 27\%) czy brak niezbędnych umiejętności oraz wiedzy w dokonywaniu zakupów online $(11 \% \text {; UE-28 }-18 \%)^{2}$.

Warto również podkreślić, że część ankietowanych nie potrafiła się jednoznacznie ustosunkować do praw przysługujących konsumentom podczas zakupu żywności przez Internet, nie zawsze też jest świadoma zasad składania reklamacji, co wskazuje na konieczność dalszego prowadzenia działań edukacyjnych skierowanych do konsumentów w tym zakresie. Jednym z przykładów takich działań jest akcja Izby

\footnotetext{
${ }^{2}$ Eurostat, http://ec.europa.eu/eurostat/data/database [dostęp: 29.01.2018].
} 
Gospodarki Elektronicznej „Kupuję w Internecie”. Jej celem jest z jednej strony popularyzacja zakupów internetowych, $\mathrm{z}$ drugiej zaś propagowanie znajomości praw z tym związanych. Aby przybliżyć konsumentom oraz przedsiębiorcom wszystkie istotne zmiany, które wprowadziła ustawa o prawach konsumenta, Urząd Ochrony Konkurencji i Konsumentów uruchomił portal internetowy. W portalu znajdziemy szczegółowe informacje dotyczące zakupów przez Internet, poza lokalem przedsiębiorstwa, a także w tradycyjnym sklepie [UOKiK 2018]. Te działania edukacyjne zapewne mogą przyczynić się do większej świadomości konsumentów z zakresu praw przysługujących im podczas zakupu żywności przez Internet.

\section{Literatura}

BALON U., 2015: Zachowania konsumentów w zakresie składania reklamacji, Handel Wewnętrzny 2 (355), 19-32.

CHU J., CHINTAGUNTA P., CEBOLlADA J., 2008: Research Note - A Comparison of Within-household Price Sensitivity Across Online and Offline Channels, Marketing Science 27 (2), 283-299.

CYREK P., 2013: Stosunek klientów do internetowych zakupów żywności, Polityki Europejskie, Finanse i Marketing 9 (58), 99-109.

DELUGA W., DYCZKOWSKA J., 2011: E-commerce - bezpieczne zakupy, Nierówności Społeczne a Wzrost Gospodarczy 22, 27-38.

European Commission, EC, 2017a: Consumer Conditions Scoreboard: Consumers at home in the Single Market - 2017 edition, http://ec.europa.eu/newsroom/just/item-detail. cfm?item id=117250 [dostęp: 15.11.2017].

European Commission, EC, 2017b: Europe's Digital Progress Report (EDPR) 2017 Country Profile Poland, https://ec.europa.eu/digital-single-market/en/scoreboard/poland [dostęp: 10.11.2017].

Gemius, 2016: E-commerce w Polsce 2016. Gemius dla e-Commerce Polska, https://ecommercepolska.pl/files/9414/6718/9485/E-commerce_w_Polsce_2016.pdf [dostęp: 20.07.2017].

Gemius, 2017: E-commerce w Polsce 2017. Gemius dla e-Commerce Polska, https://marketinginsider.pl/e-biznes/raport-e-commerce-polsce-2017-juz-dostepny [dostęp: 23.11.2017].

GĘBSKI J., KOSICKA-GĘBSKA M., TUL-KRZYSZCZUK A., 2017: Wpływ Internetu na zachowania wspótczesnych konsumentów wobec żywności, Handel Wewnętrzny 2 (367), 103-112.

GRZYWIŃSKA-RĄPCA M., GRZYBOWSKA-BRZEZIŃSKA M., 2016: Determinanty e-zakupów na rynku żywności, Roczniki Kolegium Analiz Ekonomicznych/Szkoła Główna Handlowa 40, 469-478.

KOMOR A., BUDZYŃSKA K., DOMAŃSKA K., 2015: Analiza porównawcza handlu tradycyjnego i elektronicznego, Zeszyty Naukowe Uniwersytetu Szczecińskiego. Problemy Zarządzania, Finansów i Marketingu 41 (2), 483-495.

MACIASZCZYK M., 2014: Determinanty e-wyborów konsumentów niepetnosprawnych ruchowo, Marketing i Rynek 11, 384-391. 
MAJCHRZAK-LEPCZYK J., 2015: Zachowania konsumentów na rynku e-commerce - wybrane zagadnienia, Handel Wewnętrzny 2 (355), 259-269.

Portalspożywczy.pl 2015: Sprzedaż żywności przez internet będzie szybko rosta, http://www. portalspozywczy.pl/handel/wiadomosci/sprzedaz-zywnosci-przez-internet-bedzieszybko-rosla,111919.html [dostęp: 10.07.2017].

Rozporządzenie Parlamentu Europejskiego i Rady (UE) nr 1169/2011 z dnia 25 października $2011 \mathrm{r}$. w sprawie przekazywania konsumentom informacji na temat żywności, zmiany rozporządzeń Parlamentu Europejskiego i Rady (WE) nr 1924/2006 i (WE) nr 1925/2006 oraz uchylenia dyrektywy Komisji 87/250/EWG, dyrektywy Rady 90/496/ /EWG, dyrektywy Komisji 1999/10/WE, dyrektywy 2000/13/WE Parlamentu Europejskiego i Rady, dyrektyw Komisji 2002/67/WE i 2008/5/WE oraz rozporządzenia Komisji (WE) nr 608/2004.

Urząd Ochrony Konkurencji i Konsumentów, UOKiK, 2018: Prawa konsumenta, https://prawakonsumenta.uokik.gov.pl [dostęp: 30.01.2018].

Ustawa z dnia 30 maja 2014 r. o prawach konsumenta, Dz.U. 2017, poz. 683 z późn. zm.

WOLNY R., 2016: Zmiany w zachowaniach nabywczych polskich e-konsumentów, Studia Ekonomiczne. Zeszyty Naukowe Uniwersytetu Ekonomicznego w Katowicach 270, 285-293.

\title{
The familiarity with consumer's rights purchase food on the Internet
}

\begin{abstract}
The aim of the article is an assessment of the familiarity with the rights to which the consumers are entitled when they purchase food on the Internet. The study was carried out among 600 respondents aged 25-44 years who purchase food via the Internet. The results which were obtained confirm that the kind of information that is made available by the entrepreneurs, as well as the manner in which this information is provided (which results from legal regulations), might contribute to the fact that shopping online is perceived as a good alternative for traditional shops where food can be bought. Simultaneously, it is worth noticing that a number of respondents were not able to take an unequivocal stance with regard to purchasing food online. Moreover, they are not always aware of complaint making rules, which indicates that it is necessary to conduct further educational actions targeted at the consumers in this area.
\end{abstract}

Key words: Internet, grocery shopping, consumer protection, familiarity with the rights JEL classification: D18, K15

Otrzymano: 4 grudnia 2017 r. / Zaakceptowano: 31 stycznia 2018 r. Received: 4 December 2017 / Accepted: 31 January 2018 